\title{
Influence of Crude Protein Diet on Growth Performance and Some Blood Biochemical Parameters of Growing Male Japanese Quail in Côte d'Ivoire
}

Serge-Olivier Konan Kouassi ${ }^{1}$, Mathieu Nahounou Bleyere ${ }^{2 *}$, Yves Bénarèce Tra DJE BI ${ }^{1}$, Soualio Kamagate ${ }^{3}$, Paul Angoué Yapo ${ }^{2}$ ${ }^{1}$ Laboratory of Cytology and animal Biology; Training and Research Unit of Nature Sciences, Nangui Abrogoua University; 02 BP 801 Abidjan 02 (Côte d'Ivoire)

${ }^{2}$ Physiology, Pharmacology and Pharmacopoeia Laboratory; Training and Research Unit of Nature Sciences, Nangui Abrogoua University; 02 BP 801 Abidjan 02 (Côte d'Ivoire)

${ }^{3}$ Peleforo Gon Coulibaly University Training and Research Unit of Biological Sciences (Côte d'Ivoire)

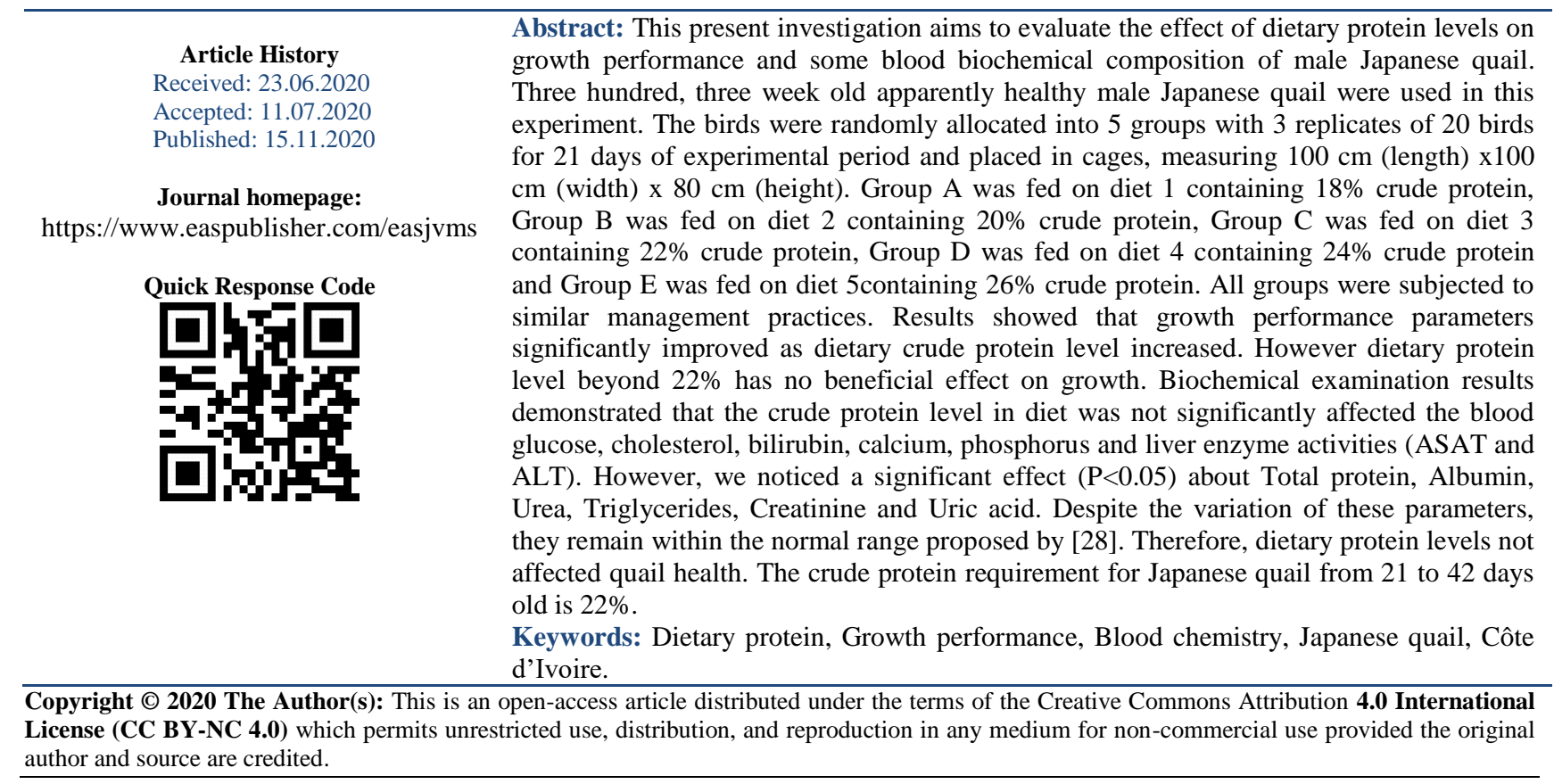
author and source are credited.

\section{INTRODUCTION}

Japanese quails (Coturnix coturnix Japonica) are a diversified poultry species reared for commercial egg and meat production. It is blessed with the unique characteristics of fast growth, early sexual maturity, high rate of egg production, short generation interval, shorter incubation period, very robust to diseases. On this base, the Japanese quail should be the choice in increasing animal protein base in the developing countries. However, the major constraint for rapid development of poultry industry is the escalating feed cost. Nutritional costs constitute about 65-70 per cent of production costs for poultry industry [1], and protein is one of the most expensive nutrients in poultry diets that its quality and quantity is considered as the main limiting factor of poultry performance and efficiency [2].
In fact, proteins and amino acids have various biological functions, including the biosynthesis of tissues and thus resulting in diverse economic products in farm animals. Dietary protein levels appear to influence the immune response levels of broiler chickens [3] and also protect quails against damaging effects of aflatoxins and other possible side effects. Reduction in dietary protein had effect on tissues weight and relative weight of the intestine. These tissues for their cell turnover had a greater need for protein [4].

Furthermore, Surai [5] reported that the serum protein reduction due to dietary protein reduction is one of the reasons for increasing free radicals activities which could be one of the reasons of reduced performance due to low protein intake. 
However, excessive protein intake results in higher nitrogen excretion and lower feed efficiency for growth and egg production, and environmental pollution.

According to Jordão Filho et al., [6] excess protein increases the oxidation of amino acid as source of energy and nitrogen excretion. Based on these studies, diet must be formulated to contain the correct amount of crude protein for optimum performance.

The Japanese quail is fairly resistant to diseases, but clinical chemistry data can be useful aids for diagnosis and monitoring responses in birds, which often show no clinical signs [7] and may provide useful information about the physical condition of individuals. Thus, this paper aimed to evaluate the effect of crude protein levels on the performance of and some serum biochemical parameters of male Japanese quail.

\section{Material ANd Methods}

A total of 300 male Japanese quail three weeks old apparently healthy male Japanese quail were used in this experiment to find out the effect of different dietary levels of protein on growth performance and some blood biochemical parameters of growing Japanese quail.

The birds were randomly allocated into 5 groups with 3 replicates of 20 birds for 21 days of experimental period and placed in cages, measuring 100 $\mathrm{cm}$ (length) $\mathrm{x} 100 \mathrm{~cm}$ (width) x $80 \mathrm{~cm}$ (height). All groups were subjected to similar management practices (brooding, lighting, feeding and watering) throughout the experiment except the diets offered. Quails were benefited from day-light (average $16 \mathrm{~h} /$ day) and water, and experimental diets were continuously available and room temperature was $37^{\circ} \mathrm{C}$. No vaccination was performed.

The experimental diets were mainly comprised of maize, soybean meal and KBC 30 (KOUDIJS protein concentrate for broiler chicken) and were formulated to meet the nutritional requirements of all nutrients, except crude protein (Table 1). The crude protein levels were obtained, mostly, by adjusting the ingredients.

Table-1: Analysed concentration of nutrients of experimental diets

\begin{tabular}{|l|c|c|c|c|c|}
\hline Ingrédients (\%) & Diet 1 & Diet 2 & Diet 3 & Diet 4 & Diet 5 \\
\hline Maize grain (yellow) & 54.5 & 54.8 & 49 & 43 & 39 \\
\hline Wheat offal & 15.5 & 10.5 & 10.5 & 10.5 & 9.5 \\
\hline K B C 30 & 26.5 & 33.0 & 37 & 42 & 46 \\
\hline Bone meal & 0.5 & 0.5 & 0.5 & 0.5 & 0.5 \\
\hline Palm oil & 3 & 1.2 & 3 & 4 & 5 \\
\hline TOTAL & 100 & 100 & 100 & 100 & 100 \\
\hline Calculated analysis & & & & & \\
\hline Metabolizable energy (Kcal/Kg) & 2799.4 & 2799.3 & 2800.8 & 2804.15 & 2801.5 \\
& $(2800)$ & $(2800)$ & $(2800)$ & $(2800)$ & $(2800)$ \\
\hline Crude protein \% & $18.05(18)$ & $19.99(20)$ & $22.03(22)$ & $24.02(24)$ & $25.94(26)$ \\
\hline Crude fiber \% & 4.25 & 4.06 & 4.22 & 4.45 & 4.15 \\
\hline Fat matter \% & 4.21 & 4.25 & 4.27 & 4.32 & 4.32 \\
\hline Calcium \% & 1.10 & 1.19 & 1.32 & 1.45 & 1.55 \\
\hline Sodium \% & 0.41 & 0.43 & 0.43 & 0.43 & 0.43 \\
\hline Phosphore \% & 3.61 & 3.14 & 3.04 & 3.04 & 2.77 \\
\hline Lysine \% & 3.00 & 3.00 & 3.01 & 3.04 & 3.03 \\
\hline Méthionine \% & 1.53 & 1.54 & 1.51 & 1.48 & 1.45 \\
\hline
\end{tabular}

Dietary treatments were used with five levels of crude protein (CP) for the five groups: Group A) protein diet (18\%); Group B) protein diet (20\%); Group C) protein diet (22\%); Group D) protein diet (24\%) and Group E) protein diet (26\%).

Feeding trial was conducted for a period of 3 weeks. Initial body weight was recorded immediately before the start of the trial and then weekly thereafter. All birds were weighed individually, before supplying morning feed and water. The feed residues were collected and weighed on the following morning to calculate the actual feed intakes. Feed intake including left over was recorded daily and was calculated from the difference between the feed supplied and it's left over. Feed conversion ratio (FCR) was recorded for the whole period as total feed intake $(\mathrm{g})$ per weight gain (g).

At the end of the experiment 30 quails in each treatment (ten in each replicate) were randomly selected. Two milliliters of blood was collected from the right jugular vein using a 23 gauge needle attached to a $5 \mathrm{ml}$ syringe and emptied into test tubes without anticoagulant. After clotting at room temperature for 2 hours, blood samples were centrifuged at $3000 \mathrm{~g}$ at room temperature for 10 minutes. The serum was then carefully aspirated with a syringe and needle and 
deposited into clean serum sample bottles and stored at $-20^{\circ} \mathrm{C}$ until analysis. Serum glucose, Triglyceride (TG), cholesterol calcium, phosphorus, potassium, Albumin (ALB), total protein (TP), uric acid, cholesterol, bilirubin, creatinine concentration and the enzyme activities of alanine aminotransferase (ALAT), aspartate aminotransferase (ASAT) were measured using biochemical auto-analyzer (Saturno 180) and its accompanying kits.

The obtained data regarding growth performance and blood parameters were subjected to analysis of variance using one-way ANOVA procedure of SAS [8]. The significant means were ranked using Duncan's Multiple Range Test [9].

\section{RESUlTS AND DisCUSSION Growth Performance}

The effects of protein level on the performance of male Japanese quail of the experiment are shown in Table 2. The initial body weight of chicks did not differ $(\mathrm{P}>0.05)$ among the dietary treatments. At the end of the experiment (day 42), there were significant differences among treatments of body weight and daily body weight gain for $\mathrm{CP}$ levels $(\mathrm{P}<0.05)$.

Final body weight at 42 days and body weight gain during 21-42 days of age of birds were increased with protein level on diet were increased up to the diet containing $24 \%$ of crude protein. This result was in agreement with the study of Sharifi et al., [10] that reported The body weight and daily weight gain (from days 1 to 42) were increased for birds received medium and higher crude protein compared with birds received low crude protein.

Table-2: Effect of dietary crude protein level on growth performance of Japanese quail during experimental period

\begin{tabular}{|l|c|c|c|c|c|c|}
\hline Parameters & Diet 1 & Diet 2 & Diet 3 & Diet 4 & Diet 5 & P \\
\hline I B W (g) & $73.22 \pm 0.37^{\mathrm{a}}$ & $73.36 \pm 0.55^{\mathrm{a}}$ & $73.29 \pm 0.73^{\mathrm{a}}$ & $73.26 \pm 0.66^{\mathrm{a}}$ & $73.52 \pm 0.58^{\mathrm{a}}$ & $\mathrm{p}>0.05$ \\
\hline F B W (g) & $143.44 \pm 3.72^{\mathrm{b}}$ & $147.14 \pm 5.02^{\mathrm{c}}$ & $158.87 \pm 3.84^{\mathrm{a}}$ & $58.64 \pm 4.63^{\mathrm{a}}$ & $152.29 \pm 6.36^{\mathrm{a}}$ & $\mathrm{p}<0.05$ \\
\hline DBGW (g) & $3.34 \pm 0.18^{\mathrm{a}}$ & $0.52 \pm 0.23^{\mathrm{c}}$ & $4.08 \pm 0.17^{\mathrm{a}}$ & $4.02 \pm 0.23^{\mathrm{a}}$ & $3.76 \pm 0.30^{\mathrm{d}}$ & $\mathrm{p}<0.05$ \\
\hline TBGW & $70.21 \pm 3.84^{\mathrm{a}}$ & $73.92 \pm 4.85^{\mathrm{c}}$ & $85.64 \pm 3.64^{\mathrm{a}}$ & $85.41 \pm 4.82^{\mathrm{a}}$ & $79.06 \pm 6.26^{\mathrm{d}}$ & $\mathrm{p}<0.05$ \\
\hline D F C & $19.36 \pm 0.74^{\mathrm{a}}$ & $19.30 \pm 0.86^{\mathrm{a}}$ & $19.09 \pm 0.82^{\mathrm{a}}$ & $19.12 \pm 0.63^{\mathrm{a}}$ & $18.55 \pm 0.66^{\mathrm{b}}$ & $\mathrm{p}<0.05$ \\
\hline C F C (g/bird) & $406.66 \pm 15.62^{\mathrm{a}}$ & $405.27 \pm 18.08^{\mathrm{a}}$ & $400.83 \pm 17.23^{\mathrm{a}}$ & $401.50 \pm 13.32^{\mathrm{a}}$ & $389.58 \pm 13.88^{\mathrm{b}}$ & $\mathrm{p}<0.05$ \\
\hline F C R & $5.80 \pm 0.32^{\mathrm{d}}$ & $5.51 \pm 0.47^{\mathrm{c}}$ & $4.69 \pm 0.27^{\mathrm{a}}$ & $4.71 \pm 0.31^{\mathrm{ab}}$ & $4.95 \pm 0.40^{\mathrm{b}}$ & $\mathrm{p}<0.05$ \\
\hline
\end{tabular}

IBW: Initial body weight; FBW: Final body weight; CFC: Cumulative feed consumption; FCR: Feed conversion ratio; DFC: Daly feed consumption; DBGW: Daily body weight gain; TBGW: total body weight gain.

Values are expressed as mean \pm standard deviation. Means in the same row had different letters significantly differ at $(\mathrm{P}<0.05)$.

In another study, Alagawany et al., [11] indicated that live body weight at 42 days and body weight gain during 21-42 and 7-42 days of age of chicks fed the $22 \%$ protein diet were increased compared with those obtained from the $20 \%$ protein diet.

According to Jafargholipour et al., [12], lower levels of dietary protein reduced final BW but considerable amount of weight loss could be prevented by adding natural and synthetic antioxidants.

Base on this study, the daily weight gain was not improved when protein level higher than $22 \%$. This result can be explained in part by lower feed intake obtained with higher levels of crude protein in diets and also due to excess protein and amino acids that are deaminated and nitrogen will be excreted in the form of uric acid by the birds [13].
Total feed consumption and daily feed consumption of the Japanese quail in this study were significantly influenced $(\mathrm{P}<0.05)$ by $\mathrm{CP}$ levels. This difference was at level of diet 5. In this group, feed consumption was lower than others groups. The high amino acid concentration due to high crude protein on diet 5 could be one of the reasons of reduced feed consumption. The observed reduction feed consumption due to an increase in diet protein level, according to Albino et al., [14] is because ), the degree of deficiency or imbalance of amino acids in the feed results in various reactions of the birds, so that the feed intake is modified. However, Total feed consumption and daily feed consumption of birds feed with diet1 to diet 4 were not statistically different. Our results agreed with studies [15, 10] and Sanguilimadan et al., [16] who found that, total feed intake and daily feed intake of the Japanese quail in this study were not significantly influenced by dietary protein level.

Data from the present study indicated that feed conversion ratio was significantly influenced $(\mathrm{P}<0.05)$ dietary protein level. In animal husbandry, feed 
conversion ratio $(\mathrm{FCR})$ or feed conversion rate is a ratio or rate measuring of the efficiency with which the bodies of livestock convert animal feed into the desired output.

In this study, quail fed $22 \%$ of crude protein in diets showed better feed conversion $(4.69 \mathrm{~g} / \mathrm{g})$ from 21 to 42 days of age. Our result was slightly below that of Bahare et al.,[17] and Dumont et al., [13] who found a better feed conversion with diet containing $23 \% \mathrm{CP}$ of European quail. This difference could be due to the environment.

\section{Plasma biochemistry and enzyme activity}

The effect of crude protein on serum chemistry of male Japanese quail is shown in table 3 . The crude protein level in diet was not significantly affected the blood glucose, Triglycerides, cholesterol, bilirubin, calcium, phosphorus and liver enzyme activities (ASAT and ALT). However, we noticed a significant effect $(\mathrm{P}<0.05)$ about Total protein, Albumin, Urea, Creatinine and Uric acid.

Table-3: Effect of dietary crude protein level on blood biochemical parameters of Japanese quail

\begin{tabular}{|c|c|c|c|c|c|c|}
\hline Parameters & Diet 1 & Diet 2 & Diet 3 & Diet 4 & Diet 5 & $\mathbf{P}$ \\
\hline Glucose (mg/dl) & $312.97 \pm 1.30^{\mathrm{a}}$ & $312.03 \pm 1.10^{\mathrm{a}}$ & $314.76 \pm 1.16^{\mathrm{a}}$ & $313.33 \pm 1.49^{\mathrm{a}}$ & $314.53 \pm 1.30^{\mathrm{a}}$ & $\mathrm{p}>0.05$ \\
\hline Total protein (mg/dl) & $3.10 \pm 0.04^{\mathrm{a}}$ & $3.61 \pm 0.04^{\mathrm{b}}$ & $3.95 \pm 0.03^{\mathrm{c}}$ & $4.46 \pm 0.02^{\mathrm{d}}$ & $5.09 \pm 0.02^{\mathrm{e}}$ & $\mathrm{p}<0.05$ \\
\hline Albumin & $1.58 \pm 0.01^{\mathrm{a}}$ & $1.98 \pm 0.015^{\mathrm{b}}$ & $2.34 \pm 0.017^{\mathrm{c}}$ & $2.65 \pm 0.022^{\mathrm{d}}$ & $2.97 \pm 0.02^{\mathrm{e}}$ & $\mathrm{p}<0.05$ \\
\hline $\operatorname{ASAT}(\mathrm{U} / \mathrm{L})$ & $258.58 \pm 1.69^{\mathrm{a}}$ & $258.04 \pm 1.46^{\mathrm{a}}$ & $258.27 \pm 1.60^{\mathrm{a}}$ & $258.81 \pm 1.52^{\mathrm{a}}$ & $258.72 \pm 1.71^{\mathrm{a}}$ & $\mathrm{p}>0.05$ \\
\hline ALAT (U/L) & $15.41 \pm 0.14^{\mathrm{a}}$ & $15.24 \pm 0.14^{\mathrm{a}}$ & $15.30 \pm 0.14^{\mathrm{a}}$ & $15.23 \pm 0.14^{\mathrm{a}}$ & $15.35 \pm 0.13^{\mathrm{a}}$ & $\mathrm{p}>0.05$ \\
\hline Urea (mg/dl) & $1.37 \pm 0.017^{\mathrm{a}}$ & $1.45 \pm 0.017^{\mathrm{a}}$ & $1.66 \pm 0.017^{\mathrm{c}}$ & $1.75 \pm 0.016^{\mathrm{d}}$ & $1.86 \pm 0.02^{\mathrm{e}}$ & $\mathrm{p}<0.05$ \\
\hline Biluribin (mg/dl) & $1.32 \pm 0.04^{\mathrm{a}}$ & $1.32 \pm 0.03^{\mathrm{a}}$ & $1.32 \pm 0.03^{\mathrm{a}}$ & $1.32 \pm 0.03^{\mathrm{a}}$ & $1.32 \pm 0.02^{\mathrm{a}}$ & $\mathrm{p}>0.05$ \\
\hline Cholesterol mmol/l & $4.89 \pm 0.07^{\mathrm{a}}$ & $4.82 \pm 0.07^{\mathrm{a}}$ & $4.89 \pm 0.07^{\mathrm{a}}$ & $4.84 \pm 0.06^{\mathrm{a}}$ & $3.14 \pm 0.017^{b}$ & $\mathrm{p}<0.05$ \\
\hline Calcium (mg/dl) & $9.54 \pm 0.06^{\mathrm{a}}$ & $9.47 \pm 0.07^{\mathrm{a}}$ & $9.44 \pm 0.06^{\mathrm{a}}$ & $9.43 \pm 0.06^{\mathrm{a}}$ & $9.42 \pm 0.03^{\mathrm{a}}$ & $\mathrm{p}>0.05$ \\
\hline Phosphorus (mg/dl) & $6.51 \pm 0.08^{\mathrm{a}}$ & $6.57 \pm 0.08^{\mathrm{a}}$ & $6.60 \pm 0.09^{\mathrm{a}}$ & $6.62 \pm 0.12^{\mathrm{a}}$ & $6.64 \pm 0.13^{\mathrm{a}}$ & $\mathrm{p}>0.05$ \\
\hline Triglycerides (mg/dl) & $90.97 \pm 1.03^{\mathrm{a}}$ & $89.26 \pm 1.00^{\mathrm{a}}$ & $90.76 \pm 1.01^{\mathrm{a}}$ & $89.92 \pm 1.06^{\mathrm{a}}$ & $89.49 \pm 1.00^{\mathrm{a}}$ & $\mathrm{p}>0.05$ \\
\hline Creatinin (mg/dl) & $0.35 \pm 0.01^{\mathrm{b}}$ & $0.39 \pm 0.01^{\mathrm{bc}}$ & $0.43 \pm 0.01^{\mathrm{ac}}$ & $0.46 \pm 0.01^{\mathrm{a}}$ & $0.47 \pm 0.01^{\mathrm{a}}$ & $\mathrm{p}<0.05$ \\
\hline Uric acid (mg/dl) & $4.47 \pm 0.12^{\mathrm{b}}$ & $4.86 \pm 0.16^{\mathrm{b}}$ & $5.45 \pm 0.12^{\mathrm{a}}$ & $5.58 \pm 0.16^{\mathrm{a}}$ & $5.64 \pm 0.13^{\mathrm{a}}$ & $\mathrm{p}<0.05$ \\
\hline
\end{tabular}

Values are expressed as mean \pm standard error. Means in the same row had different letters significantly differ at $(\mathrm{P}<0.05)$.

Plasma glucose concentration was not affected by dietary protein level. This finding are in agreement with those obtained by Kamran et al., [18] who observed that Broiler plasma glucose concentration were unaffected lowering the dietary protein content.

Similarly, Houshmand et al., [19] reported that protein level did not immunity and blood glucose concentration of broiler. In addition, Swennen et al., [20] reported that the diet not affected the carbohydrate metabolism.

In the present study, the serum total protein and albumin were increased as protein levels increased. Our result was confirmed by Tian et al., [21] who reported that total protein, albumin and Globulin in serum tended to decreased with declining dietary protein levels. The present result are also in accordance with Nazar et al., [22] who found that dietary protein level influenced significantly total protein and albumin level in blood of quail.

Enzyme activities were not affected by diets. The lack of effect on AST and ALT activities indicates that diets do not interfere with liver function. The serum enzymes AST and ALT are used as diagnostic markers for liver and muscle damage. In normal healthy animals, the serum enzymes exist at low concentrations, but increase under stressful or hepatotoxic conditions, which are usually accompanied by the inhibition of protein synthesis [23].

Serum cholesterol concentrations of quail were not significantly affected by a dietary. These results were in agreement with those of others workers who reported that serum cholesterol concentrations were not significantly altered by dietary protein levels $[10,22$, 24].

Blood uric acid and creatinine were significantly affected by dietary protein levels. This agreed with the report of Malomo et al., [25] who asserted that broiler serum uric acid and creatinine were affected by dietary protein levels. Uric acid comes from the catabolism of amino acids from food or the turnover of tissues. In this case, the increase in uric acid could have been due to an excess of ingested amino acids and the increased activity of muscle tissue in males. On the other hand, Blood uric acid is an inferential criterion for assessing the bio-availability of protein sources for broilers and such dietary protein sources with higher biological values cause a lower uric acid concentration 
in the blood serum compared with those with lower biological values [26].

Plasma triglycerides were not affected by crude protein levels. These results were in accordance with Sharifi et al., [10] and Kumar et al., [24] who argued that quail plasma triglycerides were not affected by dietary protein levels. However, divergent results were demonstrated by Swennen et al., [20] who noticed that chickens fed low crude protein diets had significantly increased plasma triglycerides.

The eventual discrepancies between results of the present study and those of previous reports would be linked to the particular sensitivity of birds (influence of species, age, sex and environmental conditions) and to the experimental protocol used (dietary nutrient composition, modalities of diet distribution and sources and type of protein).

In the present study, dietary protein levels did not induce any significant change of blood serum phosphorus and calcium. The findings are strongly confirmed the findings of Mohamed [27] who also reported that Hubbard broiler serum phosphorus, sodium and calcium were not affected by crude protein diets level.

\section{Conclusions}

It be concluded that dietary level of $22 \%$ crude protein is recommended for the feeding of growing male Japanese quail from 21 to 42 days of age. It also suggested that dietary crude protein level were not affected quail health because the parameters that have varied were within the normal range.

\section{REFERENCES}

1. FAO/WHO. (2006). Technical consultation on national food-based dietary guidelines

2. Djouvinov, D., \& Mihailov, R. (2005). Effect of low protein level on performance of growing and laying Japanese quails (Coturnix Coturnix japonica). Bulgarian Journal of Vetenary Medicine., 8 : 91-98

3. Cheema, M. A., Qureshi, M. A., \& Havenstein, G. B. (2003). A comparison of the immune profile of commercial broiler strains when raised on marginal and high protein diets. International Journal of Poultry Science; 2(5):300-312

4. Nasrin, M., Siddiqi, M. N. H., Masum, M. A. \& Wares, M. A. (2012). Gross and histological studies of digestive tract of broilers during postnatal growth and development. Journal of Bangladesh Agricultural University, 10(1): 69 77.

5. Surai, P. F. (2007). Natural antioxidants in poultry nutrition: New developments. Pages 669 - 675. In: Proceedings of the16th European Symposium on
Poultry Nutrition, Strasbourg, France, 26 - 30 August 2007.

6. Jordão, F.J., Silva, J.H.V., Costa, F.G.P., Albino, L.F.T., Melo, T.S. \& Lacerda, P.B. (2012) Requirement for maintenance and gain of crude protein for two genotypes of growing quails. Revista Brasileira de Zootecnia, 41(9):2048-2054.

7. Hall, B. D., Bodaly, R. A., Fudge, R. J. P., Rudd, J. W. M., \& Rosenberg, D. M. (1997). Food as the dominant pathway of methylmercury uptake by fish. Water, Air, and Soil Pollution, 100(1-2), 1324.

8. Fettweis, M., Sas, M., \& Monbaliu, J. (1998). Seasonal, neap-spring and tidal variation of cohesive sediment concentration in the Scheldt Estuary, Belgium. Estuarine, Coastal and Shelf Science, 47(1), 21-36.

9. Duncan, D.B., (1955). Multiple range and multiple F tests. Biometrics, 11: 1-42

10. Sharifi, M. R., Shams-Shargh, M., Dastar, B., \& Hassani, S. (2011). The effect of dietary protein levels and synbiotic on performance parameters, blood characteristics and carcass yields of Japanese quail (Coturnix coturnix Japonica). Italian Journal of Animal Science, 10(1), e4.

11. Alagawany, M., El-Hindawy, M. M., Ali, A. A., \& Soliman, M. M. (2011). Protein and total sulfur amino acids relationship effect on performance and some blood parameters of laying hens. Egypt. J. Nutr. Feeds, 14, 477-487.

12. Jafargolipour, M., Vahdatpour, T., Mahmoodpour, H., \& Vahdatpour, S. (2017). Effects of antioxidants consumption and low protein diets on liver and intestine histopathology and performance of Japanese quails (Coturnix coturnix japonica). Animal Research International, 14(1), 2683-2690.

13. Dumont, M. A., Pinheiro, S. R. F., Miranda, J. A., Pinto, F. M. P., Dias, P. C., \& Moreira, J. (2017). Proteina bruta em dietas de codornas de corte. Ciência Animal Brasileira, 18.

14. Albino, L.F.T., Silva, S.H.M., Vargas, J.G., Rostagno, H.S., Almeida \& Silva M. (1999). Níveis de metionina + cistina para frangos de corte de 1 a 21 e de 22 a 42 dias de idade. Revista Brasileira de Zootecnia, 28(3):519-525.

15. Kaur, S., Mandal, A. B., Singh, K. B., \& Narayan, R. (2006). Responses of growing Japanese quails (heavy body weight line) to graded levels of essential amino acid concentrations in diets with or without fishmeal. Journal of the Science of Food and Agriculture, 86(2), 320-327.

16. Sangilimadan, K., Asha Rajini, R., Prabakaran, R., Balakrishnan, V., \& Murugan, M. (2012). Effect of dietary protein on layer Japanese quails (Coturnix coturnix japonica) in tropics. Tamil. J. Vet. Anim. Sci, 8, 271-278.

17. Bahare, S. S., Nima, E., \& Hosein, N. (2013). The effect of decreased crude protein diets on 
performance, immune response and carcass traits of Japanese quail chickens. Annals of Biological Research, 4(2), 313-317.

18. Kamran, Z. A. H. I. D., Sarwar, M. U. H. A. M. M. A. D., Nisa, M. U., Nadeem, M. A., \& Mahmood, S. (2010). Effect of low levels of dietary crude protein with constant metabolizable energy on nitrogen excretion, litter composition and blood parameters of broilers. Int. J. Agric. Biol, 12, 401405.

19. Houshmand, M., Azhar, K., Zulkifli, I., Bejo, M. H., \& Kamyab, A. (2012). Effects of prebiotic, protein level, and stocking density on performance, immunity, and stress indicators of broilers. Poultry science, 91(2), 393-401.

20. Swennen, Q., Janssens, G. P. J., Collin, A., Le Bihan-Duval, E., Verbeke, K., Decuypere, E., \& Buyse, J. (2006). Diet-induced thermogenesis and glucose oxidation in broiler chickens: influence of genotype and diet composition. Poultry Science, 85(4), 731-742.

21. Tian, L., Cui, Y., Shi, B., Li, T., Xu, Y., \& Guo, W. (2014). Effects of low-protein diets on the blood biochemical index in broilers. Chinese Journal of Animal Science, 50(5), 56-59.

22. Nazar, S., Muhammad, M.H., \& Farhat, J. (2015). Effect of various dietary protein levels on haematology and blood biochemistry of Japanese quail International Journal of Biosciences, 7(5); 1629

23. Grunwaldt, E.G., Guevara, J.C., Estevez, O.R., Vicente, A., Rousselle, H., Alcuten, N.,
Aguerregaray, D., \& Stasi, C.R. (2005). Biochemical and haematological measurements in beef cattle in Mendoza plain rangelands (Argentina). Tropical Animal Health and Production, 37: 527-540.

24. Kumar, N.M., Selvan, S.T., Srinivasan, G., Radhakrishnan, L., Prakash, S., \& Venkataramanan, R. (2018). Effects of dietary protein and energy levels on meat quality, cholesterol, Haematology and serum biochemical parameters in Arni ducks of Tamil Nadu Journal of Entomology and Zoology Studies, 6(4): 1040-1045

25. Malomo, G. A., Bolu, S. A., \& Olutade, S. G. (2013). Effects of dietary crude protein on performance and nitrogen economy of broilers. Sustainable Agriculture Research, 2(5262016-37765).

26. Hevia, P., \& Clifford, J. (1977). Protein intake, uric acid metabolism and protein efficiency ratio in growing chicks. Journal of Nutrition, 107(6), 959964.

27. Mohamed, E. A., Ali, O. H., Malik, E. E., \& Yousif, I. A. (2012). Effect of season and dietary protein level on some haematological parameters and blood biochemical compositions of three broiler strains. International Journal of Poultry Science, 11(12), 787.

28. Agina, O.A., Ezema, W.S., \& Nwishienyi, C.N. (2017). The Haematology and Serum Biochemistry Profile of Adult Japanese Quail (Coturnix coturnix japonica) Notulac Scientia Biologicae, 9(1):67-72. 